\title{
Occult hepatitis B virus infection at patients with non viral liver disease
}

Bulent Cakal ${ }^{1}, 0000-0002-1254-844 X$

Alp Atasoy², 0000-0003-1791-897X

Bilger Cavus², 0000-0003-2203-4255

Mehves Poda ${ }^{3}, 0000-0002-1957-6072$

Mesut Bulakcı, $0000-0003-0993-6465$

Mine Gulluoglu5 , 0000-0002-3967-0779;

Mehmet Demirci6 , 0000-0001-9670-2426

Filiz Akyuz², 0000-0001-7498-141X

${ }^{1}$ Department of Medical Microbiology, Istanbul Faculty of Medicine, Istanbul University, Istanbul, Turkey.

2 Division of Gastroenterohepatology, Department of Internal Medicine, Istanbul Faculty of Medicine, Istanbul University, Istanbul, Turkey.

${ }^{3}$ Department of Genetics, Aziz Sancar Institute for Experimental Medical Research, Istanbul University, Istanbul, Turkey

${ }^{4}$ Department of Radiology, Istanbul Faculty of Medicine, Istanbul University, Istanbul, Turkey.

${ }^{5}$ Department of Pathology, Istanbul Faculty of Medicine, Istanbul University, Istanbul, Turkey.

6 Department of Medical Microbiology, Faculty of Medicine, Kirklareli University, Kirklareli, Turkey

*Corresponding author: Bülent ÇAKAL PhD, Department of Medical Microbiology, Istanbul Faculty of Medicine, Istanbul University, Istanbul, Turkey. Topkapı Mahallesi, TURGUT ÖZAL CADDESI No:118, 34093 Fatih/ISTANBUL. Tel: +90532726644. Fax: +902124142037. Email: bulentcakal@yahoo.com 


\section{Abstract}

Introduction: The presence and clinical effects of $\mathrm{OBI}$ are not clear in patients with non-viral liver disease. The objective of this study was to determine the prevalence and serological characteristics of $\mathrm{OBI}$ in patients who underwent liver biopsy due to various clinical indications, and to evaluate the interaction between the clinical and histopathological characteristics of the patients and $\mathrm{OBI}$.

Methodology: This study included $83 \mathrm{HBsAg}$ negative patients who were followed up by the Gastroenterohepatology clinic. The presence of HBV DNA was investigated by using an in-house nested PCR method from liver parenchymal biopsy samples obtained from patients who underwent due non-viral chronic liver diseases.

Results: OBI was detected in $19(22,9 \%)$ out of the 83 cases. OBI was defined in 11 (44\%) of 25 anti-HBc positive patients and 15 (31.9\%) of 47 anti-HBc and/or anti-HBs positive patients. A statistically significant correlation was found between the presence of $\mathrm{OBI}$ and anti-HBc $(p=0.003)$ and anti-HBV antibody serostatus $(p=0.025)$ of patients.

Conclusions: $\mathrm{OBI}$ could be associated with of individuals with a history of HBV exposure. Therefore, it is suggested that close virological monitoring of HBV can be helpful for improving the management of chronic liver disease and especially of patients anti-HBV antibody seropositive.

Keywords: Occult HBV infection, non-viral liver disease, hepatitis B core antibody, prevalence, liver biopsy 


\section{Introduction}

Chronic Hepatitis B virus (HBV) infection continues to be an important worldwide public health problem due to its clinical consequences such as chronic active hepatitis, liver cirrhosis, and hepatocellular carcinoma (HCC). Occult (HBV) infection (OBI) is defined as the presence of replication competent HBV DNA (i.e. episomal HBV covalently closed circular DNA [cccDNA]) in the liver and/or HBV DNA in the blood of persons testing negative for HBsAg. It is also characterized by the presence of viral replication at a low level. In the natural course of chronic HBV infection, OBI is considered as one of the likely phases which occurs as a result of the interaction of genetic, epigenetic, and immunological mechanisms that develop based on multiple factors related to the virus, the infected individual, or the environment [1-3]. The molecular basis of OBI and its pathological effects on the liver are closely linked to the HBV-specific viral lifecycle, which can be observed in the stability and long-term persistence of episomal HBV cccDNA in the nucleus of infected hepatocytes [4-7].

$\mathrm{OBI}$ alone may cause limited damage in the liver under immune-competent conditions. It may rather be a risk factor for the initial development and accelerated progression of cirrhotic and non-cirrhotic HCC when combined with other important causes of chronic liver damage such as cryptogenic liver disease, chronic hepatitis C virus (HCV) infection and alcoholic or non-alcoholic fatty-liver disease (NASH) [2, 8-21]. On the other hand, $\mathrm{OBI}$ is of clinical importance since occult virus may lead to typical new HBV infections in recipients following transmission via procedures such as blood transfusion, birth, hemodialysis, and orthotopic liver transplantation. It may further cause HBV-related liver diseases (acute and fulminant hepatitis) following reactivation in immunosuppression conditions [19, 20, 22-31]. OBI may be identified especially in residents of regions with high HBsAg seroprevalence, individuals with previous HBV and chronic HCV/HIV infection or cryptogenic hepatitis and cryptogenic cirrhosis history, HCC patients, and finally, people with hematological malignancies such as thalassemia and hemophilia [32-36].

Studies on $\mathrm{OBI}$ are usually performed to identify its role in the etiopathogenesis of advanced liver injuries such as chronic hepatitis $\mathrm{C}$, cirrhosis and HCC, to determine its clinical and histopathological effects, and to figure out its prevalence in specific patient 
groups, blood donors, and the general population. However, in most of these studies, $\mathrm{OBI}$ is diagnosed through HBV-DNA detection in patient-serum samples. Hence, such studies involving patients with advanced liver diseases (cirrhosis, HCC, etc.) hoping to detect $\mathrm{OBI}$ based on serum-level presence are bound to have limitations.

In this study, the objective was to determine the prevalence and serological profile of $\mathrm{OBI}$ in patients who underwent liver biopsy due to liver-enzyme elevation for unknown reasons, fatty-liver condition, cholestatic liver disease, and other clinical indications, and to evaluate the interaction between clinical or histopathological patient characteristics and $\mathrm{OBI}$.

\section{Methodology}

This study was supported by the Scientific Research Projects Coordination Unit of XXX with the project number TOA-2016-21643. Ethical approval of the study was provided by XXX Ethics Committee at XXX (No: 2015/1519). All patients included in this study gave informed consent for participation.

Patients: In this study, a total of $83 \mathrm{HBsAg}$ seronegative patients were included. No patients had vaccination history and prior HBV infection. They were followed up by the Gastroenterohepatology Clinic at XXX between October 2016 and November 2019 for various clinical indications. Patient DNA was obtained from liver parenchymal biopsies conducted for histopathological diagnosis and/or treatment (Table 1). Biopsy indications in the vast majority ( $80 \%$ ) of study participants were for liver disease (32 metabolic,16 cholestatic) and for liver-enzyme elevation due to unknown reasons (18). All patients were seronegative for Hepatitis $\mathrm{C}$ virus $(\mathrm{HCV})$ and human immunodeficiency virus (HIV) antibodies.

Clinical materials: Liver biopsies were performed in the Interventional Radiology Unit of the Radiology Department and in the Gastroenterohepatology Department of Internal Medicine, XXX.

Specimen collection and storage: Biopsies were performed with percutaneous needle biopsy method accompanied by ultrasound imaging, using manual method (Menghini; 17-gauge, Hepafix ${ }^{\circledR}$, B. Braun Melsungen AG 34209) in the Gastroenterohepatology Department or using automatic needles (TruCut; 18-gauge, Bard MaxCore, Covington, GA), in the Radiology Departments. One set of liver-tissue 
specimens were preserved in Hollande's fixative and sent to the Pathology Department for analysis (evaluation). A second tissue fragment or another biopsy sample was immediately snap-frozen in liquid nitrogen and kept at $80^{\circ} \mathrm{C}$ before use for nested PCR analysis.

Serum samples: Simultaneously with biopsy procedures, patients' blood samples were taken using appropriate tubes in accordance with venous blood-collection practice. After centrifugation, the sera were separated and transferred to sterile vials to be stored at $-80^{\circ} \mathrm{C}$ for later laboratory analyses.

\section{Detection of intrahepatic HBV-DNA and defining OBI}

DNA extraction from liver-biopsy specimens: Total DNA was extracted from each liver-tissue sample using a commercially avialable kit (QIAamp DNA Mini kit, Qiagen $\mathrm{GmbH}$, Hilden, Germany). Cryopreserved tissue samples were first homogenized in a homogenization buffer with the aid of TissueRuptor (QIAGEN, Hilden, Germany) and later completely lysed with proteinase $\mathrm{K}$ at $56^{\circ} \mathrm{C}$ overnight. Lastly, the total DNA was purified according to manufacturer's recommendations. DNA concentrations were determined by using a NanoDrop 2000 spectrophotometer (Thermo Fisher Scientific, USA).

Nested PCR: Total DNA extracts were subjected to four different in-house nestedPCR amplification experiments to detect the existence of (1) HBV preS-S, (2) preCoreCore, (3) Polymerase, and (4) X-viral genomic regions within the sample. Nested PCR primer sets were designed so as to cover the entire HBV genome. (Table S1) [15, 37].

Hence, viral-DNA amplification was performed at the intrahepatic level. For amplifiying the target region, initially (Nested I) the nested PCR setup $(25 \mu \mathrm{l})$ was constructed, containing $12.5 \mu \mathrm{l}$ 2X PCR master mix (HS Prime Taq Premix; GeNet Bio) and external primers $(200 \mathrm{ng} / \mu \mathrm{l})$ for amplification of $5 \mu \mathrm{l}$ DNA extract. Amplification was achieved using an initial denaturation for $10 \mathrm{~min}$ at $95^{\circ} \mathrm{C}$, and $35 \mathrm{PCR}$ cycles consisting of 30 seconds of denaturation at $95^{\circ} \mathrm{C}, 30$ seconds of annealing at $55-60^{\circ} \mathrm{C}$, extension at $72^{\circ} \mathrm{C}$ for 30 seconds, followed by a final extension step of $10 \mathrm{~min}$ at $72^{\circ} \mathrm{C}$. In the second step of the nested PCR setup, amplification was performed similarly to Nested I, using $5 \mu$ of the first PCR product and its matching internal primers for the amplification of the main target region. All PCR reactions were performed in the T100 Thermal Cycler (Bio-Rad) instrument. 
For patients with overt chronic-B infection who served as positive controls, HBV plasmid (4.1 kbp) material was used to standardize nested PCR and DNA obtained from liver biopsy samples. To eliminate false-negative results and to demonstrate the existence of proper-quality DNA, the human beta-globin gene was used as target. DNA from individuals serving as negative controls without HBV infection were kept in sterile distilled water. In this study, the sensitivity limit for nested PCR was set as $10 \mathrm{HBV}$ plasmid DNA copies / PCR reactions. The obtained PCR products were subjected to electrophepheresis containing $2 \%$ agarose and evaluated using a gel imaging system. The presence of HBV DNA specific to the target region and intended size was checked in comparison with a 100 bp DNA marker (100bp DNA Marker; GeNet Bio) used as a reference.

Defining OBI: After amplification with nested PCR, amplification positivity of at least 2 viral genomic regions was considered positive for OBI.

Clinical laboratory data: Demographic and pre-biopsy patient data were obtained from patient files or the hospital's electronic data management system (Table 1).

Serology markers/assays and serum HBV DNA: Serum antibodies to hepatitis B surface (anti-HBs) and hepatitis B core (anti-HBc) antigens were analyzed with Elecsys Anti-HBs II and Elecsys Anti-HBc II kit/Cobas e411® (Roche Diagnostics, Mannheim, Germany) respectively according to manufacturer's instructions. HBV DNA was extracted from serum samples using QIAsymphony DSP Virus/Pathogen Midi Kit (Qiagen $\mathrm{GmBH}$, Hilden, Germany) according to manufacturers instructions and then HBV DNA viral load detection was performed by using Artus HBV QS-RGQ kit (Qiagen $\mathrm{GmBH}$, Hilden, Germany) with a linear range from 31.6 to more than $2.0 \times 107 \mathrm{IU} / \mathrm{mL}$ on the Rotor-Gene $Q$ instrument (Qiagen $\mathrm{GmBH}$, Hilden, Germany).

Liver histopathology: Histology of liver biopsy specimens was evaluated by Department of Pathology of XXX. Liver biopsy samples were fixed in a formalin solution and stained with Masson's trichrome. Pathology reports contained histological parameters including fibrosis, portal and lobular inflammation, lobular necrosis, steatosis, cholestasis, and bile duct damage. NAFLD was defined as the observation of abnormal lipid accumulation (hepatic steatosis) in more than $5 \%$ of hepatocytes. $\mathrm{NASH}$ was defined as the presence of lobular inflammation together with ballooning (hepatocyte damage) and hepatic steatosis, with or without fibrosis [38]. In 
histopathological diagnosis, the presence of minimal portal or lobular inflammatory infiltrates, absence of fibrosis, and absence of structural changes were considered as non-specific histological findings.

Statistical analysis: For statistical data analysis, SPSS (21.0, SPSS Inc., Chicago, IL) was used. For comparisons involving categorical variables, the Chi-square test and/or Fisher's exact test was used. For non-categorical data, normality was checked using the Shapiro-Wilk test and ANOVA was used for comparisons. Results are provided as means and standard deviations. Results with $p$-values less than 0.05 were considered statistically significant.

\section{Results}

Prevelance of $O B I$ in liver tissue: In this study, we have detected the presence of HBV DNA at the intrahepatic level in 19 (22.9\%) of $83 \mathrm{HbsAg-negative} \mathrm{patients} \mathrm{whose}$ liver biopsy was performed due to the clinical indications specified in Table 1. On the others hand, Serum HBV DNA was not detected in serum sample of any patients

Demographic, clinical laboratory parameters and OBI: Demographic, clinical, laboratory, serological, and clinical data of 83 patients are outlined in Table 1. 38 patients were male $(45.8 \%$ of the total) and 45 female $(54.2 \%)$. The mean age of the study population was 47.5 , with SD of 13.8 . In our study, no statistically significant correlation was found between $\mathrm{OBI}$ presence and patients' demographic characteristics including gender and age. Further, clinical parameters including patients' liver enzymes (ALT, AST, ALP, GGT), bilirubin levels, and INR, AFP, albumin levels were not significantly correlated with $\mathrm{OBI}$ presence either.

OBI and anti-HBV antibody profile: The patients' anti-HBV antibody serostatus/profile is summarized in Table 1. In this sample, 25 (30.1\%) were found positive for anti-HBc antibodies only, $43(51.8 \%)$ for anti-HBs antibodies only, and 47 (56.6\%) for both (seropositive) anti-HBc and anti-HBs antibodies. Among the 19 patients detected to have $\mathrm{OBI}, 11(57.9 \%)$ were positive for anti-HBc antibodies, 15 (78.9\%) positive for both anti-HBc and anti-HBs (seropositive), and 4 (21.1\%) negative (seronegative) for both anti-HBV anbodies. OBI was defined in 11 (44\%) of 25 anti$\mathrm{HBc}$ positive patients and $15(31.9 \%)$ of 47 anti-HBc and/or anti-HBs positive patients. In the others hand, $\mathrm{OBI}$ was defined in $8(13.8 \%)$ of 58 anti-HBc negative patients and $4(11.1 \%)$ of 36 anti-HBc and/or anti-HBs negative patients. A statistically significant 
correlation was found between the presence of $\mathrm{OBI}$ and anti-HBc $(p=0.003)$ and antiHBV antibody serostatus ( $p=0.025)$ of patients. Anti-HBs antibodies were positive in 12 patients (63.2\%) with $\mathrm{OBI}$ and in 31 (48.4\%) without. There was no statistically relationship difference between OBI presence and anti-HBs antibody profile $(p=0.259)$.

\section{Liver Histopatology:}

OBI and hepatic steatosis: Histopathological findings related to liver parenchymal biopsies of the patients are shown in Table 2. The most prevalent histopathological finding was Liver/hepatic steatosis with a total of 33 patients $(39,8 \%)$, where 22 $(26,5 \%)$ were NASH and 11 (13.2) NAFLD. Among these patients, OBI was detected in $7(31,8 \%), 2(18.2 \%)$ and $9(27,3 \%)$, respectively. There was no statistically significant difference in terms of $\mathrm{OBI}$ occurrence between patients with and without hepatic steatosis, and patients with NASH and NAFLD (Table 3).

OBI and non-specific liver histology: Biopsy indications / clinical histories and antiHBV serological profiles of 23 patients who exhibited non-specific histopathological / histological changes are summarized in Table 4. In this group, 7 patients (30.4\%) were detected to have OBI. Liver biopsies were performed on 6 patients with a pre-diagnosis of cryptogenic liver disease, on 10 receiving immunosuppressive and/or immunosuppressive therapy due to hematological and autoimmune / autoinflammatory disease, and on 3 with elevated autoimmune antibodies. OBI was detected in 3 (50\%), $3(33.3 \%)$, and $1(33.3 \%)$ patients, respectively. However, OBI was not detected in 2 patients with cholestatic liver disease, 1 with liver steatosis, and 1 with malignant disease (colorectal cancer). In this group, OBI was detected in 7 (77.8\%) of 9 anti-HBC positive patients and in 4 (40\%) of 10 anti-HBs positive patients (Table 4). Anti-HBclgG antibodies were positive in 3 patients (100\%) with cryptogenic liver disease prediagnosis, in 2 patients (50\%) with autoimmune / autoinflammatory disease, and in 1 patient $(100 \%)$ with hematological malignancy who were all determined to have OBI. One patient with $\mathrm{OBI}$ who underwent biopsy due to elevated autoimmune antibodies was negative for serum anti-HBclgG antibody. In this group, four patients who were not determined to have $\mathrm{OBI}$, anti-HBclgG antibodies were negative (Table 4).

OBI and Cholestatic Liver disease: HBV DNA was not detected in the liver tissue of any of the 14 patients whose histopathological findings were consistent with cholestatic liver disease (Table 2). 
OBI and other liver diseases: OBI was detected in 3 (23.1\%) out of 13 patients $(15,7 \%$ of the total sample), of which 4 were reported to have cirrhosis, 4 vascular liver damage, 3 toxic hepatitis, 1 autoimmune hepatitis, and 1 granulomatous liver disease consistent histopathological findings (Table 2). In this group of 3 patients with $\mathrm{OBI}, 1$ had vascular liver damage, 1 had cirrhosis, and 1 had toxic hepatitis. HBV DNA was not detected in the liver parenchymal tissues of 2 patient exhibiting autoimmune hepatitis and (apparently) granulomatous liver disease.

\section{Discussion}

OBI was detected in 19 (22.9\%) out of 83 patients included in this study, which was conducted to evaluate the prevalence of $O B I$ at intrahepatic level and its association with clinical and histopathological findings in patients who underwent liver biopsy for various clinical indications. Demographic and clinical laboratory data obtained as part of this study point out to the difficulty of finding measurable specific parameters indicating or predicting the presence of OBI (Table 1).

Serologically, OBI may be categorised as seropositive and seronegative. According to the literature, in most OBI cases (80\%) patients test positive for HBV antibodies [20, 37]. In our study, patients with $\mathrm{OBI}$ had a serological profile that is $78.9 \%$ seropositive and $21.1 \%$ seronegative. Therefore; the data (Table 1) obtained from serological profiles of patients with $\mathrm{OBI}$ support the use of anti-HBc IgG in routine clinical practice as a predictive biomarker for the prevention of possible HBV reactivations, especially for patients who are in immunosuppressed state and/or recieving immunosuppressive therapy [39].

OBI prevalence may exhibit differences depending on many factors such as the clinical profile of the patient group, geographic location (HBV endemicity), co-infection with other viruses, vaccination, immunological status, and laboratory diagnostic methods / procedures [32-36]. On the other hand, there are only a few published studies on intrahepatic HBV detection determining the prevalence and role of $\mathrm{OBI}$ in chronic liver disease. In a study conducted to determine HBV DNA at the intrahepatic level in patients with normal liver histology, OBI prevalence was found to be $16.3 \%$ [27]. In another study determining HBV DNA based on serum obtained from HBsAg negative healthy individuals, cryptogenic chronic liver patients, and patients with $\mathrm{HCC}, \mathrm{OBI}$ prevalence was found to be $10.6 \%, 28.3 \%$, and $70.4 \%$, and anti-HBclgG positivity 
percentage $33.3 \%, 100 \%$, and $86.7 \%$, respectively [34]. In our study using patients with various clinical and histopathological characteristics as the research sample, OBI prevalence was $22.9 \%$ overall and $31.8 \%$ in the sub-group with histopathologically defined hepatocyte damage such as $\mathrm{NASH}$. It is suggest that OBI prevalence could be assaociated with liver damage of patients and HBV endemicity levels.

Although OBI incidence was higher among NASH patients than NAFLD patients and other subgroups (except for patients with non-specific histopathological changes), no statistically significant difference was found $\mathrm{OBI}$ frequency across patient groups (Table 2 and 3). This might be due to the modest sample size. In a study conducted by Raimondo $G$ et al. in patients with morbid obesity, $O B I$ was detected in $4.5 \%$ of patients with NAFLD and in $20.9 \%$ of patients with NASH. In this respect, it has been suggested that $\mathrm{OBI}$ may be both a risk factor for the development of $\mathrm{NASH}$ and a cofactor that increases its progression [40]. In our study, hepatic steatosis was found in $9(47.4 \%)$ out of 19 patients with OBI. The findings indicate that the relatively increased frequency of $\mathrm{OBI}$ in patients with $\mathrm{NASH}$, the presence of $\mathrm{NASH}$-related hepatocyte damage in the in the formation of $\mathrm{OBI}$ and on the other hand, $\mathrm{OBI}$ may increase progression of fibrosis in patients with NASH. Nuclear receptors (NR) play a critical role in hepatic lipid and glucose metabolism as well as transcriptional regulation of HBV biosynthesis. In this respect, to regulate the impaired lipid metabolism and hepatic steatosis at the hepatocyte level, NR expression increases and may activate the transcription of HBV and promote viral replication. Ultimately, futher research is needed to determine the histopathological relationship between NASH and OBI [41, 42].

In another study involving 101 patients diagnosed with cryptogenic liver disease characterized by persistent transaminase elevation and HBsAg seronegativity, 19 patients $(18.8 \%)$ were reported to have OBI. Among the 49 patients who were histopathologically defined as having non-specific changes and NASH, OBI was detected in 7 (14,3\%). Among 39 patients with chronic hepatitis and 13 with chirrosis, OBI was found in $30,7 \%$ and $61,5 \%$, respectively [43]. The aforementioned study has similarities with our findings (table 2) regarding the presence and prevalance of $\mathrm{OBI}$ in patients with histological nonspecific changes and NASH who are monitored due to their elevated liver enzymes with unknown aetiology. 
Several studies reported that the presence and frequency of $\mathrm{OBI}$ increase is parallel to level of liver damage in cryptogenic hepatitis, cirrhosis, cirrhotic HSC, and noncirrhotic HSC patients and also HBV endemicity [10, 18, 31]. In our study of clinically pre-diagnosed Cryptogenic (chronic) liver disease patients, findings regarding $O B I$ presence and anti-HBclgG positivity taken together indicate that $\mathrm{OBI}$ may have a role in the etiopathogenesis of this disease. Therefore, evaluating the presence of $\mathrm{OBI}$ in such patients living in regions with high HBV contact risk (endemicity rate) may make clinical management more effective.

The conditions and potency of immunosuppression may be associated with $\mathrm{OBI}$ presense and life-threatening HBV reactivation risk [1, 19, 20, 44]. The data obtained in this study indicates that, in addition to liver damage, immunosuppression conditions may also promote OBI (Table 2 and 4). This points to the determining role of host factors including immunity, rather than viral factors in the pathogenesis of OBI. Based on these data, it may also be predicted that the neutralization capacity of anti-HBs, which is an indicator of HBV immunization, may be limited in patients with OBI [44 ]. Itimately, in HBsAg negative, anti-HBc seropositive immunosuppressive patients, regardless of their anti-HBs serostatus, evaluation of $\mathrm{HBV}$ reactivation risk might be recommended.

Although the limited number of patients with liver cirrhosis (Table 4) in our study makes it difficult to make a confident deduction, individuals with a history of high HBV contact risk and hepatocyte damage, especially in cases of cryptogenic cirrhosis, may be at risk for $\mathrm{OBI}$. In studies involving patients with intrahepatic cholangiocarcinoma and autoimmune hepatitis, OBI prevalence was reported as $61.7 \%$ and $23.3 \%$, respectively $[45,46]$. The absence of $\mathrm{OBI}$ in our study in these subgroups may be an artifact of smaller sample size (Table 4).

In our study, serum HBV DNA was not detected in any of the patients who were OBI diagnosis. This situation supports the idea that low level of replication competence of $\mathrm{OBI}$ and $\mathrm{OBI}-$ related HBV viremia are characterized by temporal fluctuations [1-47].

The limitations of this study include the unequal distribution of study subgroups and their partially insufficient numbers.

Histopathological and clinical effects of $\mathrm{OBI}$ accompanying chronic liver injuries are not yet clear [48]. In a retrospective study involving patients with various clinical conditions 
such as HBV exposure, immunosuppression, HIV co-infection, and liver injury, it has been stated that $\mathrm{OBI}$ is a heterogeneous condition associated with the specified clinical conditions [49]. In that study, attention has been drawn to the risk of HBV reactivation, especially when immunosuppression conditions are present, despite the presence of anti-HBs. Eventually, presence of persistent and low level of replication competent HBV DNA in hepatocytes may induce mild liver necroinflammation and cause liver damage. In addition, immunosuppression conditions may raise HBV reactivation risk. Other than that, $\mathrm{OBI}$ accompanying chronic liver damage as a cofactor may contribute to the progression of liver damage $[2,48,50]$.

\section{Conclusion}

In conclusion, the results of this study suggest that a close virological monitoring of HBV may be useful for more effective clinical management of possible OBI-related complications, especially in cases where the patient has a seroprofile where HBsAg is negative and anti-HBclgG and/or anti-HBVantibodies are positive. With such monitoring, clinical management of possible OBI-related complications could be more effective, especially in patients with chronic hepatocyte damage, patients with cryptogenic liver disease like NASH, and immunosuppressed patients.

\section{Acknowledgements}

We are grateful to $X X X(X X)$ for the plasmid HBVDNA (4.1 kbp). We also are indebted to nurses $X X X$ and $X X X(X X X)$ and $X X X(X X X)$ for technical assistance. 


\section{References}

1. Raimondo G, Locarnini S, Pollicino T, Levrero M, Zoulim F, Lok AS, and the Taormina Workshop on Occult HBV Infection Faculty Members. Update of the statements on biology and clinical impact of occult hepatitis B virus infection. J Hepatol. 2019;71(2):397-408.

2. European Association for the Study of the Liver. Electronic address eee, European Association for the Study of the L. EASL 2017 Clinical Practice Guidelines on the management of hepatitis B virus infection. J Hepatol. 2017;67(2):370-98.

3. Raimondo G, Caccamo G, Filomia R, Pollicino T Occult HBV infection. Semin Immunopathol. 2013; 35:39-52.

4. Dandri M, Locarnini S. New insight in the pathobiology of hepatitis B virus infection. Gut 2012;61(Suppl 1):6-17.

5. Mason AL, Xu L, Guo L, Kuhns M, Perrillo RP. Molecular basis for persistent hepatitis B virus infection in the liver after clearance of serum hepatitis $B$ surface antigen. Hepatology. 1998; 27:1736-42.

6. Yang $\mathrm{H}-\mathrm{C}$ and $\mathrm{KaO} \mathrm{J}-\mathrm{H}$. Persistence of hepatitis B virus covalently closed circular DNA in hepatocytes: molecular mechanisms and clinical significance. Emerg Microbes Infect. 2014 Sep;3(9):e64.

7. Zoulim F. New insight on hepatitis $B$ virus persistence from the study of intrahepatic viral cccDNA. J Hepatol. 2005;42:302-308.

8. Brechot $C$. Pathogenesis of hepatitis $B$ virus-related hepatocellular carcinoma: old and new paradigms. Gastroenterology 2004;127(5):56-61.

9. Coppola N, Onorato L, lodice V, Starace M, Minichini C, Farella N et al. Occult HBV infection in HCC and cirrhotic tissue of HBsAg-negative patients: a virological and clinical study. Oncotarget 2016;7(38):62706-62714.

10. Covolo L, Pollicino T, Raimondo G, Donato F. Occult hepatitis B virüs and the risk for chronic liver disease: a meta-analysis. Dig Liver Dis 2013;45:238-244.

11. De Mitri MS, Cassini R, Bernardi M. Hepatitis B virus-related hepatocarcinogenesis: molecular oncogenic potential of clear or occult infections. Eur J Cancer 2010; 46: 21782186.

12. Mak LY, Wong DK-H, Pollicino T, Raimondo G, Hollinger FB, Yuen M-F. Occult hepatitis $B$ infection and hepatocellular carcinoma: Epidemiology, virology, hepatocarcinogenesis and clinical significance. J Hepatol 2020; doi: 10.1016/j.jhep.2020.05.042.

13. Nishikawa $H$, Osaki Y. Clinical significance of occult hepatitis $B$ infection in Progression of liver disease and carcinogenesis. J Cancer 2013;4(06):473-480.

14. Pollicino T, Saitta C, Raimondo G. Hepatocellular carcinoma: the point of view of the hepatitis B virus. Carcinogenesis 2011; 32: 1122-1132. 
15. Pollicino T, Squadrito G, Cerenzia G, Cacciola I, Raffa G, Craxi A, et al. Hepatitis B virus maintains its pro-oncogenic properties in the case of occult HBV infection. Gastroenterology 2004;126:102-110.

16. Saitta C, Tripodi G, Barbera A, Bertuccio A, Smedile A, Ciancio A, et al. Hepatitis B virus (HBV) DNA integration in patients with occult HBV infection and hepatocellular carcinoma. Liver Int 2015;35:2311-2317.

17. Shi Y, Wu YH, Wu W, Zhang WJ, Yang J, Chen Z. Association between occult hepatitis B virus infection and the risk of hepatocellular carcinoma: a meta-analysis. Liver Int 2012; 32: $231-240$.

18. Shim CW, Park J-W, Kim SH, Kim JS, Kim BH, Kim SH et al. Noncirrhotic hepatocellular carcinoma: etiology and occult hepatitis B virus infection in a hepatitis B virus-endemic area. Therap Adv Gastroenterol. 2017;10(7):529-536.

19. Squadrito G, Spinella R, Raimondo G. The clinical significance of occult HBV infection. Ann Gastroenterol. 2014;27(1):15-19.

20. Torbenson M, Thomas DL. Occult hepatitis B. Lancet Infect Dis. 2002;2:479-486.

21. Wong DK-H, Cheng SCY, Mak LL-Y, To EW-P, Lo RC-L, Cheung T-T et al. Among Patients with Undetectable Hepatitis B Surface Antigen and Hepatocellular Carcinoma, a High Proportion Has Integration of HBV DNA into Hepatocyte DNA and No Cirrhosis. Clin Gastroenterol Hepatol. 2020;18(2):449-456.

22. Allain JP, Cox L. Challenges in hepatitis B detection among blood donors. Curr Opin Hematol 2011; 18: 46-466.

23. Chemin I, Trepo C. Clinical impact of occult HBV infections. J Clin Virol 2005; 34: 15-21.

24. Cheung CK, Lo CM, Man K, Lau GK. Occult hepatitis B virus infection of donor and recipient origin after liver transplantation despite nucleoside analogue prophylaxis. Liver Transpl 2010; 16: 1314-1323.

25. Fabrizi F, Messa PG, Lunghi G, Aucella F, Bisegna S, Mangano S, et al. Occult hepatitis $B$ virus infection in dialysis patients: a multicentre survey. Aliment Pharmacol Ther 2005; 21: $1341-1347$.

26. Raffa G, Maimone S, Cargnel A, Santantonio T, Antonucci G, Massari M, et al. Analysis of occult hepatitis B virus infection in liver tissue of HIV patients with chronic hepatitis C. AIDS 2007; 21: 2171-2175.

27. Raimondo G, Navarra G, Mondello S, Costantino L, Colloredo G, Cucinotta E. et al. Occult hepatitis B virus in liver tissue of individuals without hepatic disease. J Hepatol. 2008;48:743-746.

28. Raimondo G, Pollicino T, Squadrito G. What is the clinical impact of occult hepatitis B virus infection? Lancet 2005;365(9460):638-640. 
29. Torbenson M, Kannangai R, Astemborski J, Strathdee SA, Vlahov D, Thomas DL. High prevalence of occult hepatitis B in Baltimore injection drug users. Hepatology 2004;39:5157.

30. Toyoda H, Hayashi K, Murakami Y, Honda T, Katano Y, Nakano I, et al. Prevalence and clinical implications of occult hepatitis B viral infection in hemophilia patients in Japan. J Med Virol 2004; 73: 195-199.

31. Wong DK, Huang FY, Lai CL, Poon RT, Seto WK, Fung J, et al. Occult hepatitis B infection and HBV replicative activity in patients with cryptogenic cause of hepatocellular carcinoma. Hepatology 2011; 54: 829-836.

32. Gutiérrez-García ML, Fernandez-Rodriguez CM, Lledo-Navarro JL, Buhigas-Garcia I. Prevalence of occult hepatitis B virus infection. World J Gastroenterol. 2011;17(12):15381542.

33. Brechot C, Thiers V, Kremsdorf D, Nalpas B, Pol S, Paterlini-Bréchot P. Persistent hepatitis $B$ virus infection in subjects without hepatitis B surface antigen: clinically significant or purely "occult"? Hepatology. 2001; 34(1):194-203.

34. Fang Y, Shang Q-L, Liu J-Y, Li D, Xu W-Z, Teng X, et al. Prevalence of occult hepatitis B virus infection among hepatopathy patients and healthy people in China. J Infect. 2009; 58:383-8.

35. Ohba K, Kubo S, Tamori A, Hirohashi K, Tanaka H, Shuto T, et al. Previous or occult hepatitis $B$ virus infection in hepatitis $B$ surface antigen negative and anti-hepatitis $C$ negative patients with hepatocellular carcinoma. Surg Today 2004; 34: 842-848.

36. Pisaturo M, Onorato L, Russo A, Coppola N. Prevalence of occult HBV infection in Western countries. J Med Virol 2020; doi: 10.1002/jmv.25867.

37. Raimondo G, Allain JP, Brunetto MR, Buendia MA, Chen DS, Colombo M et al. Statements from the Taormina expert meeting on occult hepatitis B virus infection. J Hepatol. 2008;49:652-57.

38. EASL-EASD-EASO. EASL-EASD-EASO clinical practice guidelines for the management of non-alcoholic fatty liver disease. J Hepatol 2016; 64: 1388-1402.

39. Caviglia GP, Abate ML, Tandoi F, Ciancio A, Amoroso A, Salizzoni M et al. Quantitation of HBV cccDNA in anti-HBc-positive liver donors by droplet digital PCR: A new tool to detect occult infection. J Hepatol. 2018;69(2):301-307.

40. Raimondo G, Saitta C, Lombardo D, Giraudi PJ, Rosso N, leni A et al. Occult hepatitis B virus infection predicts non-alcoholicsteatohepatitis in severely obese individuals from Italy Liver Int, 2020:40(7):1601-1609.

41. Reese V, Ondracek C, Rushing C, Li L, Oropeza CE, McLachlan A. Multiple nuclear receptors may regulate hepatitis $B$ virus biosynthesis during development. The International Journal of Biochemistry \& Cell Biology 43 (2011) 230-237. 
42. Wagner M, Zollner G, Trauner M. Nuclear Receptors in Liver Disease. Hepatology 2011;53:1023-1034.

43. Berasain C, Betés M, Panizo A, Ruiz J, Herrero J I, Civeira M-P et al. Pathological and virological findings in patients with persistent hypertransaminasaemia of unknown aetiology Gut 2000;47:429-435.

44. Sagnelli E, Pisaturo M, Martini S, Filippini P, Sagnelli C, Coppola N. Clinical impact of occult hepatitis B virus infection in immunosuppressed patients. World J Hepatol 2014; 6:384-393.

45. Chen X-X, Xiang K-H, Zhang H-P, Kong X-S, Huang C-Y, Liu Y-M et al. Occult HBV infection in patients with autoimmune hepatitis: A virological and clinical study. J Microbiol Immunol Infect. 2020;53(6):946-954.

46. Pollicino T, Musolino C, Saitta C, Tripodi G, Lanza M, Raffa G et al. Free episomal and integrated HBV DNA in HBsAg-negative patients with intrahepatic cholangiocarcinoma. Oncotarget. 2019;10(39):3931-3938.

47. Espositoa A, Sabiaa C, lannonea C, Giovanni F, Nicolettib GF, Sommesea L et al. Occult Hepatitis Infection in Transfusion Medicine: Screening Policy and Assessment of Current Use of Anti-HBc Testing Transfus Med Hemother 2017;44:263-272.

48. Yuki N, Nagaoka T, Yamashiro M, Mochizuki K, Kaneko A, Yamamoto K et al. Long-Term Histologic and Virologic Outcomes of Acute Self-Limited Hepatitis B. Hepatology. 2003;37(5):1172-9.

49. Malagnino M, Fofana DB, Lacombe K, Gozlan J. Occult Hepatitis B Virus Infection: An Old Entity With Novel Clinical Involvements. Open Forum Infect Dis. 2018 14;5(10):227.

50. Bläckberg J, Kidd-Ljunggren K. Occult hepatitis B virus after acute self-limited infection persisting for 30 years without sequence variation. J Hepatol 2000; 33: 992-997. 
Table 1: Demographic, clinical laboratory, serological, virological and clinical characteristics of the patients

\section{Data}

Mean age \pm SD (years)

Gender (M/F)

Clinical laboratory

$\operatorname{ALT}(\mathrm{U} / \mathrm{L})$, Mean $\pm S D$

AST $(U / L)$, Mean $\pm S D$

ALP $(U / L)$, Mean $\pm S D$

GGT (U/L), Mean $\pm S D$

Total bilirubin $(\mathrm{mg} / \mathrm{dl})$, Mean $\pm \mathrm{SD}$

Direct bilirubin $(\mathrm{mg} / \mathrm{dl})$, Mean \pm SD

Indirect bilirubin $(\mathrm{mg} / \mathrm{dl})$, Mean $\pm S D$

INR, Mean \pm SD

AFP $(\mathrm{ng} / \mathrm{ml})$, Mean \pm SD

Albumin $(\mathrm{g} / \mathrm{dl})$, Mean \pm SD

Platelet count $\left(10^{6} / \mathrm{ml}\right)$, Mean $\pm S D$

\section{HBV serology}

Anti-HBc positive $n(\%)$

Anti-HBc negative $n(\%)$

Anti-HBs positive $\mathrm{n}(\%)$

Anti-HBs negative $\mathrm{n}(\%)$

Seropositive OB

Anti-HBc and/or Anti-HBs positive n (\%)

\section{Seronegative $\mathrm{OB}$}

Anti-HBc and Anti-HBs negative $n$ (\%)

\section{Serum HBV DNA}

\section{Liver biopsy indications/Clinical}

Metabolic liver disease

Cholestatic Liver disease ${ }^{* *}$

Elevated liver enzymes unknown of cause

Elevated autoimmune antibodies

Cirrhosis by imaging

Vascular liver disorders ${ }^{* * *}$

Toxic hepatitis

Granulomatous liver diseases
All Patients

$\mathrm{n}=83$

$47,48 \pm 13,81$

$38 / 45$

$114,23 \pm 141,29$

$96,69 \pm 148,85$

$171,40 \pm 207,59$

$174,51 \pm 246,14$

$1,00 \pm 1,46$

$0,59 \pm 1,28$

$1,00 \pm 0,12$

$1,00 \pm 0,12$

$3,64 \pm 3,38$

$4,31 \pm 0,59$

$223,53 \pm 77,03$

$$
\begin{aligned}
& 25(30,1 \%) \\
& 58(69,9 \%) \\
& 43(51,8 \%) \\
& 40(48,2 \%)
\end{aligned}
$$

$47(56,6 \%)$

$36(43,4 \%)$

Not detected

$32(38,5)$

$16(19,3)$

$18(21,7)$

$5(6,0)$

$4(4,8)$

$4(4,8)$

$3(3,6)$

$1(1,2)$

\section{$\begin{array}{ll}\text { OBI Negative } & \text { OBI Positive } \\ \mathrm{n}=64(77,1 \%) & \mathrm{n}=19(22,9 \%)\end{array}$}

$44,42 \pm 11$

$48,39 \pm 14,35$

$28 / 36$

$10 / 9$

0,274

0,495

$102,34 \pm 110,90$

$88,97 \pm 128,93$

$186,10 \pm 231,98$

$154,26 \pm 213,78$

$121,89+67,89$

$188,47 \pm 272,54$

$1,07 \pm 1,58$

$0,67 \pm 1,40$

$1,01 \pm 0,08$

$1,00 \pm 0,078$

$3,79 \pm 3,78$

$4,31 \pm 0,62$

$230,27 \pm 80,97$

0,239

$27,47 \pm 113,96 \quad 0,346$

$0,92 \pm 0,77 \quad 0,681$

$0,49 \pm 0,58 \quad 0,586$

$0,97 \pm 0,21 \quad 0,310$

$0,97 \pm 0,20 \quad 0,31$

$3,16 \pm 1,34 \quad 0,473$

$4,32 \pm 0,52 \quad 0,971$

$200,84 \pm 58,16 \quad 0,145$

$14(21,9 \%) \quad 11(57,9 \%) \quad \underline{\mathbf{0 , 0 0 3}}$

$50(78,1 \%) \quad 8(42,1 \%)$

$31(48,4 \%) \quad 12(63,2 \%)$

$7(36,8 \%)$

$33(51,6 \%)$

$15(78,9 \%)$

$32(50,0 \%)$

$\underline{0,025}$

$4(21,1 \%)$

Not detected Not detected

INR; international normalized ratio, AFP; serum alpha-fetoprotein.

son's disease

${ }^{* *}$ Cholestatic Liver disease; Biliary disease (primary biliary cholangitis; PBC, primary sclerosing cholangitis; PSC)

***Portal hypertension/ venopathy 
Table 2: Liver Histopatology

\begin{tabular}{|c|c|c|c|}
\hline & $\begin{array}{l}\text { All patients } \\
n=83\end{array}$ & $\begin{array}{l}\text { OBI negative } \\
n=64\end{array}$ & $\begin{array}{l}\text { OBI positive } \\
n=19\end{array}$ \\
\hline \multicolumn{4}{|l|}{ Liver biopsy } \\
\hline Liver steatosis/ Hepatic steatosis & $33(39,8)$ & $24(72,7)$ & $9(27,3)$ \\
\hline $\mathrm{NASH}^{*}$ & $22(26,5)$ & $15(68,2)$ & $7(31,8)$ \\
\hline NAFLD** & $11(13,2)$ & $9(71,8)$ & $2(18,2)$ \\
\hline Non-specific changes ${ }^{* * *}$ & $23(27,7)$ & $16(69,6)$ & $7(30,4)$ \\
\hline \multicolumn{4}{|l|}{ Others } \\
\hline Cholestatic Liver disease ${ }^{* * *}$ & $14(16,9)$ & $14(100)$ & $0(0)$ \\
\hline Cirrhosis & $4(4,8)$ & $3(75)$ & $1(25,0)$ \\
\hline Portal hypertension / Venopathy & $4(4,8)$ & $3(75)$ & $1(25)$ \\
\hline Toxic hepatitis & $3(3,6)$ & $2(66,7)$ & $1(33,3)$ \\
\hline Granulomatous liver diseases & $1(1,2)$ & $1(100)$ & $0(0)$ \\
\hline Autoimmune hepatitis & $1(1,2)$ & $1(100)$ & $0(0)$ \\
\hline
\end{tabular}


Table 3: Liver steatosis and $O B I$ frequency Histopathology (n)

No Liver steatosis (50) Liver steatosis (33) OBI negative n (\%)

$40(80,0)$

$24(72,7)$

$15(68,2)$

OBI positive

$\mathbf{P}$

NASH (22)

$9(71,8)$

n (\%)

NAFLD (11)

No NASH (61)

$49(80,3)$

$10(20,0)$

$9(27,3)$

0,517

$7(31,8)$

$2(18,2)$

0,448

$12(19,7)$

0,311 
Table 4: Biopsy indication/ clinical history and $O B I$ in patients with non-specific changes

\begin{tabular}{|c|c|c|c|c|c|c|c|}
\hline \multirow[b]{2}{*}{ n (\%) } & \multicolumn{3}{|c|}{ İmmunosuppressive patients $(n=10)$} & \multirow[b]{2}{*}{$\begin{array}{c}\text { Elevated } \\
\text { autoimmune } \\
\text { antibodies } \\
3(13,0)\end{array}$} & \multirow[b]{2}{*}{$\begin{array}{c}\text { Cholestatic } \\
\text { Liver disease } \\
2(8,7)\end{array}$} & \multirow[b]{2}{*}{$\begin{array}{c}\text { Liver } \\
\text { Steatosis } \\
1(4,3)\end{array}$} & \multirow[b]{2}{*}{$\begin{array}{c}\text { Malignant } \\
\text { disesase }^{* *} \\
1(4,3)\end{array}$} \\
\hline & $\begin{array}{l}\text { Cryptogenic } \\
\text { liver disease } \\
6(26,1)\end{array}$ & $\begin{array}{c}\text { Autoimmune / } \\
\text { Autoinflammatory diseases } \\
6(26,1)\end{array}$ & $\begin{array}{c}\text { Hematological } \\
\text { malignancy } \\
4(17,4)\end{array}$ & & & & \\
\hline $\begin{array}{c}\text { OBI } \\
\text { negative } \\
(n=16)\end{array}$ & $3(50)$ & $4(66,7)$ & $3(75)$ & $2(66,7)$ & $2(100)$ & $1(100)$ & $1(100)$ \\
\hline $\begin{array}{l}\text { OBI } \\
\text { positive } \\
(n=7)\end{array}$ & $3(50)$ & $2(33,3)$ & $1^{*}(25)$ & $1(33,3)$ & 0 & 0 & 0 \\
\hline $\begin{array}{c}\text { Anti-HBc } \\
\text { positive } \\
(n=9)\end{array}$ & $4(66,7)$ & $3(50)$ & (25) & $1(33,3)$ & 0 & 0 & 0 \\
\hline $\begin{array}{c}\text { Anti-HBs } \\
\text { positive } \\
(n=10) \\
\text { Anti- } \\
\text { HBclgG } \\
\text { and OBI } \\
\text { positive } \\
(n=5)\end{array}$ & $4(66,7)$ & $3(50)$ & $1^{*}(100)$ & $1(33,3)$ & 0 & 0 & $1(100)$ \\
\hline
\end{tabular}

